\title{
Kinerja Jabatan Fungsional Perekayasa di Lingkungan Pusat Penelitian dan Pengembangan Jalan dan Jembatan
}

\author{
Suhendar \\ Litbang PU Provinsi Jawa barat \\ Suh3ndar@gmail.com
}

\begin{abstract}
ABSTRAK
Hasil penelitian tentang Kinerja Jabatan Fungsional Perekayasa di Lingkungan Pusat Penelitian dan Pengembangan Jalan Dan Jembatan, menunjukkan bahwa: (1). Variabel kepemimpinan (X1) mempunyai pengaruh positif yang kuat terhadap kinerja jabatan fungsional perekayasa (Y) sebesar 36,5\%. (2).Variabel kompensasi (X2) mempunyai pengaruh positif namun sangat lemah terhadap kinerja jabatan fungsional perekayasa (Y) sebesar 3\%. (3). Secara simultan variabel kepemimpinan dan kompensasi berpengaruh terhadap kinerja, dengan koefisien korelasi $\mathrm{R}=0,612$ atau determinan $\mathrm{R} 2$ sebesar 0,375 atau sebesar 37,5\%. Dengan demikian kepemimpinan dan kompensasi harus dapat menciptakan Kondisi kerja yang mendukung kenyamanan pribadi atau faktor-faktor lingkungan yang akan dapat meningkatkan kinerja pegawai.
\end{abstract}

Kata kunci: kepemimpinan, kompensasi dan kinerja

\begin{abstract}
The results of research on the Performance of Functional Position of Engineers in the Environment of Center of Research and Development of Road and Bridge, showed that: (1) Leadership variable (X1) has a strong positive effect on performance of functional position of engineer $(Y)$ equal to 36,5\%. (2) The compensation variable (X2) has a positive but very weak effect on the performance of the functional position of the engineer $(Y)$ of $3 \%$. (3) Leadership and compensation variables affect simultaneously to the performance, with correlation coefficient $R=$ 0.612 or determinant $R 2$ of 0.375 or $37.5 \%$. Thus, leadership and compensation should be able to create boosting working conditions personal comfort or environmental factors that will improve employee performance.
\end{abstract}

Key words: leadership, compensation and performance

\section{PENDAHULUAN}

Tidak dapat dipungkiri bahwa sumber daya manusia (SDM) merupakan salah satu unsur yang paling penting di dalam suatu organisasi. Keberhasilan suatu organisasi tergantung pada peranan SDM dalam mengelola organisasi dan memajukan organisasi itu sendiri. Untuk menciptakan situasi organisasi yang lebih baik maka diperlukan pengelolaan SDM secara tepat, sehingga dapat menciptakan SDM yang berkualitas. Kemudian untuk menciptakan sumber daya manusia yang berkualitas baik, diperlukan suatu Manajemen Sumber Daya Manusia (MSDM), yang merupakan upaya untuk mengarahkan dan mengelola SDM di dalam organisasi agar mampu berperilaku dan berpikir sebagaimana yang diharapkan oleh organisasi. Oleh karena itu kedudukan sumber daya manusia di dalam suatu organisasi mempunyai peranan yang sangat penting dan menentukan, baik itu dipandang sebagai perancang maupun pelaksana dalam merencanakan, merumuskan, dan melaksanakan berbagai kegiatan dalam organisasi untuk mencapai tujuan yang telah ditetapkan.

Sumber daya aparatur memegang peran strategis dalam melakukan perubahan pada sebuah organisasi serta menjadi dasar bagi pencapaian tujuan organisasi. Dengan demikian sumber daya aparatur merupakan faktor strategis dalam suatu perubahan organisasi karena kemampuan manusia berubah dan berkembang serta menyesuaikan diri dengan lingkungannya. 
Sumber daya manusia merupakan komponen yang penting dan sentral bagi seluruh kegiatan, karena tinggi rendahnya keberhasilan kerja suatu organisasi sangat tergantung kepada kualitas sumber daya manusianya. Instansi Pusat Penelitian dan Pengembangan (Litbang) Jalan dan Jembatan Bandung merupakan instansi yang menyelenggarakan penelitian dan pengembangan di bidang jalan dan jembatan. Berdasarkan Peraturan Menteri PUPR No. 20/PRT/M/2016 tentang Organisasi dan Tata Kerja Unit Pelaksana Teknis di Kementerian Pekerjaan Umum dan Perumahan Rakyat, instansi ini mempunyai tugas untuk melaksanakan penelitian dan pengembangan teknologi terapan dan penyelenggaraan perumusan standar bidang jalan dan jembatan. Untuk operasionalnya instansi ini didasarkan pada kebijakan teknis oleh Kepala Badan Penelitian dan Pengembangan (Ka.Balitbang) Kementerian Pekerjaan Umum dan Perumahan Rakyat.

Tugas Pusat Penelitian dan Pengembangan Jalan dan Jembatan Bandung sesuai dengan Peraturan Menteri Pekerjaan Umum Nomor. 20/PRT/M/2016, adalah melaksanakan penelitian dan pengembangan teknologi terapan dan penyelenggaraan perumusan standar bidang jalan dan jembatan. Pelaksanaan penelitian dan pengembangan tentunya harus ditunjang dengan pengembangan SDM yang berkesinambungan untuk mencapai tujuan yang diharapkan. Apalagi jumlah kegiatan yang dilaksanakan Pusat Penelitian dan Pengembangan Jalan dan Jembatan Bandung setiap tahunnya terus meningkat.

Faktor kepemimpinan dan kompensasi bagi pegawai menjadi perhatian dalam rangka meningkatkan kinerja pegawai yang dapat mempengaruhi tingkat efisiensi dan efektivitas organisasi. Penelitian yang dilakukan terkonsentrasi pada pengaruh kepemimpinan dan kompensasi terhadap kinerja jabatan fungsional perekayasa, karena dalam rangka meningkatkan kinerja pejabat fungsional di Instansi Puslitbang Jalan dan Jembatan, faktor kepemimpinan dan kompensasi merupakan hal yang penting.

Dari hasil pengamatan yang telah dilakukan pada saat pra survei diperoleh gambaran sementara, bahwa kepemimpinan serta pemberian kompensasi dirasakan belum berjalan sebagaimana mestinya sehingga belum dapat meningkatkan kinerja pejabat fungsional perekayasa.

\section{TINJAUAN PUSTAKA}

Seorang pemimpin kedudukannya dalam suatu kelompok atau organisasi menjadi penting, karena pemimpin dapat memberikan petunjuk untuk menjalankan atau mengoperasikan suatu sistem yang telah dibuat/direncanakan. Seperti disebutkan dalam Al Qur'an Surat As Sajdah (32: 24), "Dan kami jadikan di antara mereka itu pemimpin-pemimpin yang memberi petunjuk dengan perintah kami selama mereka sabar. Mereka meyakini ayat-ayat kami”.

Menurut Terry dan Rue (2015:192) "Pemimpin ialah sebagai kemampuan seseorang atau pemimpin, untuk mempengaruhi perilaku orang lain menurut keinginan-keinginanya dalam suatu keadaan tertentu. Kepemimpinan adalah suatu pertumbuhan alami dari orang-orang yang berserikat untuk suatu tujuan dalam suatu kelompok". Beberapa orang dalam kelompok itu dapat memimpin dan sebagian besar orang mengikuti. Sebenarnya, kebanyakan orang menginginkan seseorang untuk menentukan yang seharus diperbuat dan bagaimana membuatnya.

Seorang pemimpin menerima tanggungjawab dan berhasrat untuk menjalankan keputusan-keputusan untuk persoalan-persoalan tertentu. Seorang pemimpin mengenal dan memahami kebutuhan-kebutuhan dari bawahannya. Seringkali, inilah yang menjadi akibat untuk mengembangkan suatu lingkungan saling pengertian, yang timbul dari sidang-sidang partisipasi dan konsultasi. Seorang pemimpin melaksanakan rencana-rencana kegiatan dan memberikan sumbangannya untuk menjadikan sebuah rencana menjadi suatu kenyataan.

Hasil penelitian J. Sterling Livingston dalam George R. Terry dan Rue (2015:197), meneliti hubungan antara harapan manajer dan hasil pekerjaan yang dicapai oleh bawahan. Jika harapan manajer itu tinggi, maka mungkin produkivitas tinggi pula. Sebaliknya jika harapan manajer itu rendah, maka produktivitas bawahan itu mungkin rendah pula.

Pendapat-pendapat Livingston itu disimpulkan sebagai berikut, yang diharapkan seorang manajer dari bawahannya dan bagaimana memperlakukan 
mereka, sangat menentukan pekerjaan mereka serta kemajuan karirnya. Sebuah ciri khas tunggal dari para manajer yang unggul adalah kemampuan mereka menciptakan harapan-harapan besar mengenai pekerjaan, yang dipenuhi orang-orang bawahan. Manajer yang kurang giat gagal untuk mengembangkan harapan-harapan yang serupa dan sebagai suatu akibatnya, produktivitas orang-orang bawahannyapun menderita karenanya. Lebih sering seorang bawahan melakukan yang mereka percaya diharapkan dari mereka (pemimpin) untuk dibuat.

Peran utama seorang pemimpin ialah memengaruhi orang lain untuk sukarela mencapai sasaran yang telah ditetapkan. Pemimpin menciptakan visi dan menginspirasi orang lain untuk mencapai visi tersebut dan memperluas diri mereka diluar kapabilitas normalnya. Sedangkan manajer merencanakan aktivitas, mengorganisir struktur yang sesuai dan mengontrol sumber daya.

Kepemimpinan (leadership) adalah kemampuan untuk memengaruhi suatu kelompok menuju pencapaian sebuah visi atau tujuan yang ditetapkan, Robbins (2015:249). Seorang pemimpin harus bisa memberikan panutan dan dapat memotivasi karyawan supaya target yang ditetapkan oleh perusahaan dapat tercapai.

Pemimpin dalam suatu organisasi memiliki peran, menurut Rivai (2014:596), "Peran pemimpin adalah menyusun arah perusahaan, mengkomunikasikan ini dengan karyawan, memotivasi para karyawan, dan melakukan tinjauan jangka panjang”.

Peran seorang pemimpin sangat menentukan bagi pertumbuhan dan kelangsungan hidup sebuah perusahaan, kepemimpinan memegang peranan penting bagi sukses atau tidaknya sebuah perusahaan. Tanpa kepemimpinan yang efektif, sebuah perusahaan ibarat kapal tanpa nahkoda yang bisa membawanya ke tujuan. Pemimpin harus dapat menyelesaikan dan memutuskan suatu masalah pada perusahaan serta dapat menjadikannya tolak ukur bagi keberlanjutan hidup perusahaan sehingga pemimpin dapat memberi contoh yang baik kepada para karyawan.

Menurut Mc Shane dan Von Glinow (2010: 360) dalam Wibowo (2016:280), menyatakan bahwa "Kepemimpinan adalah tantangan memengaruhi, memotivasi dan memungkinkan orang lain memberikan kontribusi kearah efektivitas dan keberhasilan organisasi dimana mereka menjadi anggotanya". Kepemimpinan adalah proses mempengaruhi dan mendukung orang lain untuk bekerja secara antusias menuju pada pencapaian sasaran (Newstrom, 2011:171).

Kepemimpinan merupakan faktor yang penting dalam membantu individu atau kelompok mengidentifikasi tujuannya. Pemimpin harus memotivasi bawahannya dalam mencapai produktivitas, dengan tujuan untuk pencapaian tujuan yang telah ditetapkan sebelumnya.

Colqiutt, Lepine dan Wesson (2011: 483) dalam Wibowo (2016:280) mendefinisikan kepemimpinan sebagai penggunaan kekuasaan dan pengaruh untuk mengarahkan aktivitas pengikut kearah pencapaian tujuan. Arah tersebut dapat mempengaruhi interpretasi kejadian pengikut, organisasi aktivitas pekerjaan mereka, komitmen mereka terhadap tujuan utama, hubungan mereka dengan pengikut atau akses mereka pada kerjasama dan dukungan dari unit kerja lain.

Menurut Gibson, Ivancevich, Donnely dan Konopske (2012) dalam Wibowo (2016:281), menyatakan bahwa "Kepemimpinan adalah suatu usaha menggunakan pengaruh untuk memotivasi individu menyelesaikan beberapa tujuan". Pengertian ini mengandung makna bahwa kepemimpinan menyangkut penggunaan pengaruh dan semua hubungan interpersonal, pentingnya menjadi agen perubahan dan memfokuskan pada penyelesaian suatu masalah.

Dari pendapat para pakar terdapat kesamaan, kepemimpinan ialah merupakan kemampuan mempengaruhi orang lain dengan menggunakan kekuasaan. Kepemimpinan ialah suatu proses interaksi antara pemimpin dan pengikut, kepemimpinan terjadi pada berbagai tingkatan dalam suatu organisasi serta kepemimpinan memusatkan perhatian pada penyelesaian tujuan yang ingin dicapai bersama.

Kepemimpinan merupakan suatu peran yang dirumuskan sebagai rangkaian perilaku yang teratur, ditimbulkan karena suatu jabatan tertentu, atau karena adanya suatu organisasi yang mudah dikenal. Keperibadian seseorang dapat mempengaruhi bagaimana peran harus dijalankan. Peran timbul karena pemimpin memahami bahwa ia tidak bekerja 
sendirian, pemimpin mempunyai lingkungan yang setiap saat diperlukan untuk berinteraksi.

Peran kepemimpinan oleh Mintberg dalam Thoha (2005:266) terbagi atas tiga peranan, ketiga peranan itu ialah sebagai berikut:

1) Peranan sebagai figurehead, yakni suatu peran yang dilakukan untuk mewakili organisasi yang dipimpinnya di dalam setiap kesempatan dan persoalan yang timbul secara formal. Peran ini sangat besar dan sederhana, karena otoritas formalnya, maka pimpinan dianggap sebagai simbol dan berkewajiban untuk melaksanakan serangkaian tugas-tugas.

2) Peran sebagai pemimpin (leader), dalam peranan ini manajer bertindak sebagai pemimpin, mereka melakukan hubungan interpersonal dengan yang dipimpin, dengan melakukan fungsi-fungsi pokoknya diantaranya memimpin, memotivasi, mengembangkan, dan mengendalikan. Dalam organisasi informal biasanya pemimpin diikuti karena mempunyai kekuasaan karismatik atau kekuasaan fisik.

3) Peran sebagai pejabat perantara (liaison manager), disini manajer melakukan peranan yang berintegrasi dengan teman sejawat, staff dan orang-orang lain yang berada diluar organisasinya untuk mendapatkan informasi. Oleh karena itu organisasi yang dipimpin manajer itu tidak berdiri sendirian, maka manajer meletakkan peranan pejabat perantara untuk memperbanyak hubungan dengan sejumlah individu atau kelompok-kelompok tertentu yang berada diluar organisasinya.

Dari pengertian tersebut dapat disimpulkan bahwa kepemimpinan merupakan penggerak utama perusahaan. Pemimpin mempengaruhi para karyawan untuk melaksanakan pekerjaannya sesuai dengan tujuan yang ditetapkan oleh perusahaan. Selain itu pemimpin juga harus bisa memotivasi para karyawan agar terpacu untuk mencapai tujuan tersebut.

Dari pendapat para ahli di atas, maka untuk membahas mengenai kepemimpinan digunakan penjelasan yang diambil dari Schermerhorn (2011) dalam Emron, Yohny dan Imas (2016:111) yang berpendapat bahwa "Kepemimpinan adalah proses menginspirasi orang lain untuk bekerja keras guna menyelesaikan tugas-tugas penting”.
Dari pendapat di atas dan kaitannya dengan masalah yang harus dipecahkan, maka yang dimaksud pemimpin adalah: bahwa setiap pemimpin harus dapat memberikan inspirasi bagi pegawainya agar dapat bekerja keras, memberikan motivasi bagi pegawai agar dapat menyelesaikan setiap tugas yang dibebankan dengan penuh semangat mencapai hasil yang telah ditetapkan.

Menurut Schermerhorn (2011) dalam Emron, Yohny dan Imas (2016:111) berpendapat bahwa "Kepemimpinan adalah proses menginspirasi orang lain untuk bekerja keras guna menyelesaikan tugas-tugas penting". Sejalan dengan pendapat tersebut Emron Edison, dan kawan-kawan (2016:111) mengemukakan bahwa indikator-indikator kepemimpinan ialah sebagai berikut:

1) Memiliki strategi bisnis yang jelas dan realitas;

2) Strategi bisnis dikomunikasikan dengan baik kepada anggota;

3) Anggota percaya terhadap pemimpin dalam melakukan perubahan kearah yang lebih baik;

4) Memberikan perhatian dan memotivasi kerja anggota;

5) Peduli terhadap setiap permasalahan yang dihadapi para anggota;

6) Memperhatikan lingkungan dan kenyamanan bekerja;

7) Merangsang anggota untuk membekali diri dengan pengetahuan dan keahlian dalam usaha meningkatkan kompetensi;

8) Merangsang anggota untuk memiliki tekad dalam menyelesaikan tugas;

10. Mengajak seluruh anggota untuk berorientasi pada kualitas;

11. Mengajak anggota untuk bekerja dalam tim yang solid dan harmonis;

12. Menyelesaikan setiap konflik antar anggota dengan baik;

13. Menghargai setiap perbedaan pendapat untuk tujuan yang lebih baik;

14. Mengajak seluruh anggotanya untuk menghormati perbedaan dan keyakinan.

Kualitas sifat atau karakter seorang pemimpin menentukan kepemimpinannya. Kualitas tersebut tidak dapat di turunkan kepada orang lain, karena pada kenyataannya memang bahwa tidak semua orang bisa menjadi seorang pemimpin. Oleh karena itu setiap proses kepemimpinan dalam keunikannya memiliki keunikan masing-masing, tidak dapat melepaskan diri dari kondisi yang bersifat dan 
bernilai manusiawi. Pemimpin ialah manusia serta orang yang dipimpin juga merupakan manusia, dalam hal ini apabila proses kepemimpinan dilaksanakan secara tidak manusiawi, maka berbagai masalah akan terjadi yang akan berakibat pada proses pencapaian tujuan tidak akan efektif.

Dalam kenyataannya tidak menutup kemungkinan bahwa kepemimpinan itu dapat diperoleh melalui pelatihan dan pengalaman. Oleh sebab itu setiap orang yang memiliki potensi pemimpin atau orang yang dipersiapkan sebagai pemimpin dapat dilatih menjadi pemimpin. Potensi tersebut akan muncul apabila seseorang telah memperoleh latihan kepemimpinan.

Dalam kenyataannya tidak semua pemimpin adalah pimpinan, demikian pula sebaliknya tidak semua pimpinan adalah pemimpin. Hanya karena suatu organisasi memberikan hak-hak formal tertentu kepada para pimpinannya, bukan jaminan bahwa mereka mampu memimpin dengan efektif. Kita menemukan bahwa kepemimpinan nonformal yaitu kemampuan untuk memengaruhi orang lain yang muncul dari luar struktur formal organisasi, merupakan hal yang penting atau malah lebih penting daripada pengaruh formal.

Kompensasi merupakan suatu kenyataan yang tidak dapat disangkal bahwa motivasi dasar bagi kebanyakan orang menjadi pegawai pada suatu organisasi atau perusahaan ialah untuk mencari nafkah. Artinya seseorang menggunakan pengetahuan, keterampilan, tenaga dan waktunya untuk berkarya pada suatu organisasi, di lain pihak pegawai mengharapkan menerima imbalan tertentu.

Berangkat dari pandangan demikian, dewasa ini masalah kompensasi dipandang sebagai salah satu tantangan yang harus dihadapi oleh manajemen suatu organisasi. Dikatakan merupakan tantangan karena kompensasi oleh para pekerja tidak lagi dipandang semata-mata sebagai alat pemuas kebutuhan materielnya, tetapi sudah dikaitkan dengan harkat dan martabat manusia. Sebaliknya organisasi cenderung melihatnya sebagai beban yang harus dipikul oleh organisasi tersebut dalam rangka upaya pencapaian tujuan dan berbagai sasarannya.

Seperti yang disebutkan dalam Al Qur'an Surat An Nahl (16: 97) "Barangsiapa yang mengerjakan amal shaleh, baik laki-laki maupun perempuan dalam keadaan beriman, maka sesungguhnya akan kami berikan kepadanya kehidupan yang baik dan sesungguhnya akan kami beri balasan kepada mereka dengan pahala yang lebih baik dari apa yang telah mereka kerjakan." Pahala yang dimaksud dalam surat ini adalah balasan yang setimpal dari Allah, serta upah atau kompensasi sebagai balas jasa atas pekerjaan yang telah kita kerjakan.

Dalam Undang-Undang Nomor 24 Tahun 2011 tentang Badan Penyelenggara Jaminan Sosial (BPJS), definisi gaji disandingkan dengan upah yang isinya menyatakan bahwa, "Gaji atau upah adalah hak pekerja yang diterima dan dinyatakan dalam bentuk uang sebagai imbalan dari pemberi kerja kepada pekerja yang ditetapkan dan dibayar menurut suatu perjanjian kerja, kesepakatan, atau peraturan perundang-undangan, termasuk tunjangan bagi pekerja dan keluarganya atas suatu pekerjaan dan / atau jasa yang telah atau akan dilakukan".

Menurut Emron Edison, dan Kawan-kawan (2016:153) "Gaji didefinisikan sebagai upah, sedangkan komponen gaji pokok atau upah pokok merupakan komponen dari gaji atau upah. Namun apapun yang diterima atas segala sesuatu sebagai imbalan dapat pula disebut dengan kompensasi”.

Kompensasi adalah "Sesuatu yang diterima karyawan atas jasa yang mereka sumbangkan pada pekerjaannya. Mereka menyumbangkan apa saja yang menurut mereka berharga, baik tenaga maupun pengetahuan yang dimiliki. Seorang pekerja sebagai tukang pikul barang merasa bahwa kekuatan fisik yang dimiliki adalah sesuatu yang berharga mereka sumbangkan atas pekerjaannya". (Wilson Bangun 2012) dalam Emron Edison, dan Kawan-kawan (2016:154).

Rivai dan kawan-kawan (2014:541) mengemukakan, "Kompensasi merupakan sesuatu yang diterima karyawan sebagai pengganti kontribusi jasa mereka pada perusahaan". Kompensasi merupakan biaya utama atas keahlian atau pekerjaan dan kesetiaan dalam bisnis perusahaan pada abad ke-21 ini. Kompensasi menjadi alasan utama mengapa kebanyakan orang mencari pekerjaan.

Menurut Wibowo (2007:348), bahwa pengertian kompensasi adalah "Kontra prestasi terhadap penggunaan tenaga atau jasa yang telah diberikan oleh tenaga kerja. Kompensasi merupakan jumlah 
paket yang ditawarkan organisasi kepada pekerja sebagai imbalan atas penggunaan tenaga kerjanya."

Kompensasi merupakan hal yang penting karena dapat menjadi pendorong bagi seorang karyawan untuk bekerja. Seorang karyawan menggunakan pengetahuan, keterampilan, tenaga dan waktu bukan semata-mata ingin membuktikan atau mengabdikan diri pada perusahaan atau suatu organisasi, tetapi ada tujuan lain yaitu mengharapkan imbalan atau balas jasa atas hasil yang telah diberikan.

Ambar Teguh Sulistiyani dan Rosidah (2003:206), mendefinisikan "Kompensasi adalah segala sesuatu yang diterima oleh pegawai sebagai balas jasa (kontra prestasi) atas kerja mereka". Pada dasarnya kompensasi merupakan kontribusi yang diterima oleh pegawai atas pekerjaan yang telah dikerjakannya.

Kompensasi yang diberikan kepada karyawan dapat berpengaruh pada kondisi kerja karyawan, oleh karena itu dalam menetapkan kompensasi yang dikaitkan dengan prestasi kerja atau produktivitas sangatlah penting. Sehingga selain dapat terwujudnya efisiensi dan efektivitas karyawan dapat juga ditujukan untuk kelangsungan aktivitas organisasi dan rencana-rencana perusahaan pada waktu yang akan datang.

Sedarmayanti (2016:263), mendefinisikan kompensasi sebagai "Segala sesuatu yang diterima oleh karyawan sebagai balas jasa kerja mereka, dengan tujuan adalah untuk menghargai kinerja, menjamin keadilan, mempertahankan karyawan, memperoleh karyawan bermutu, mengendalikan biaya dan memenuhi peraturan."

Dari definisi di atas maka suatu imbalan dapat dikatakan baik, dimana adanya sistem yang mampu menjamin kepuasan para anggota organisasi yang pada gilirannya memungkinkan organisasi memperoleh, memelihara dan mempekerjakan sejumlah orang yang dengan berbagai sikap dan prilaku positif bekerja dengan produktif bagi kepentingan organisasi.

Menurut Werther dan Davis dalam Sedarmayanti (2011:236) "Kompensasi ialah apa yang diterima pekerja sebagai tukaran atas kontribusinya kepada organisasi". Hal tersebut jelas terlihat bahwa ada balas jasa, yang diterima oleh seseorang dari pimpinannya terhadap besar atau kecilnya kontribusi dalam suatu organisasi.

Untuk membantu organisasi mencapai keberhasilan strategis sambil memastikan keadilan internal dan eksternal. Keadilan internal memastikan jabatan yang lebih menantang, atau orang memiliki kualifikasi lebih baik dalam organisasi dibayar lebih tinggi. Keadilan eksternal menjamin pekerjaan mendapat kompensasi adil dalam perbandingan dengan pekerjaan yang sama di pasar tenaga kerja.

Menurut Thomas H. Stone dalam Suwanto dan Priansa (2016:220) mendefinisikan "Compensation is any from of payment to employees for work they provide their employer". Artinya kompensasi adalah setiap bentuk pembayaran yang diberikan kepada karyawan sebagai pertukaran pekerjaan yang mereka berikan kepada majikan.

Sedangkan menurut Edwin B. Flippo dalam Suwanto dan Priansa (2016:220) mendefinisikan "Compensation as adequate and equitable remuneration of personal for their contribution to organization objectives". Artinya kompensasi merupakan pemberian imbalan jasa yang layak dan adil kepada karyawan-karyawan karena mereka telah memberi sumbangan kepada pencapaian organisasi.

Dengan demikian kompensasi mempunyai arti yang luas, selain terdiri dari gaji dan upah, dapat pula berbentuk fasilitas perumahan, fasilitas kendaraan, pakaian seragam, tunjangan keluarga, tunjangan kesehatan, tunjangan pangan dan masih banyak lagi yang dapat dinilai dengan uang serta cenderung diterima oleh karyawan secara tetap.

"Kompensasi adalah total dari semua penghargaan yang diberikan pada pegawai sebagai imbalan atas jasa yang mereka berikan kepada organisasi”, Sinambela (2016:216). Tujuan keseluruhan memberikan kompensasi ialah untuk menarik, mempertahankan dan memotivasi pegawai. Kompensasi finansial langsung (direct financial compensation) terdiri dari bayaran yang diterima seseorang dalam bentuk upah (wage), gaji (salary), komisi dan bonus. Kompensasi finansial yang tidak langsung/benefit (indirect financial compensation) terdiri dari semua reward finansial yang tidak dicakup dalam kompensasi langsung.

Kompensasi (compensation) meliputi imbalan finansial dan non-finansial serta tunjangan yang 
diterima oleh para karyawan sebagai bagian dari hubungan kepegawaian. "Kompensasi merupakan sesuatu yang diterima oleh para karyawan sebagai ganti kontribusi mereka kepada organisasi” (Simamora, 2004:442). Kompensasi dibagi dalam dua bentuk: pertama kompensasi langsung (direct compensation) dan kompensasi tidak langsung (indirect compensation). Menurut Simamora (2004:442) "Kompensasi finansial langsung (direct financial compensation) terdiri dari bayaran (pay) yang diperoleh seseorang dalam bentuk gaji, upah, bonus, dan komisi. Kompensasi finansial tidak langsung (indirect financial compensation) yang disebut juga dengan tunjangan, meliputi semua imbalan finansial yang tidak tercakup dalam kompensasi langsung”. Kompensasi merupakan hal yang dipertimbangkan dalam pemberiannya kepada pegawai, karena harus memenuhi rasa keadilan serta dapat menumbuhkan semangat kerja dalam pencapaian tujuan organisasi.

Kompensasi didefinisikan oleh Sedarmayanti (2016:263), "Kompensasi adalah segala sesuatu yang diterima oleh karyawan sebagai balas jasa kerja mereka". Tujuan pengelolaan kompensasi ialah membantu organisasi mencapai keberhasilan strategis dan menjamin hak internal dan eksternal secara adil.

Kepentingan pekerja harus mendapat perhatian, dalam arti kompensasi tersebut memungkinkannya mempertahankan taraf hidup yang wajar dan layak serta hidup mandiri tanpa menggantungkan pemenuhan berbagai jenis kebutuhannya kepada orang lain.

Karyawan atau pegawai bukan hanya sekedar asset utama organisasi, tetapi merupakan serangkaian modal manusia (human capital) yang memiliki peran sangat menentukan bagi kemajuan sebuah organisasi, karena merekalah yang menjadi penggerak seluruh aktivitas organisasi. Pemberian kompensasi merupakan aktivitas manajemen sumber daya manusia, yang antara lain bertujuan untuk menyediakan tenaga kerja yang berkualitas baik. Secara komprehensif kompensasi juga dapat menjadi pendorong semangat kerja yang tinggi bagi seluruh karyawan, sehingga tujuan organisasi dapat tercapai.

Suparyadi (2015:271) mendefinisikan, "Kompensasi adalah keseluruhan imbalan yang diterima oleh karyawan sebagai penghargaan atas kontribusi yang diberikannya kepada organisasi, baik bersifat finansial maupun non finansial". Dari definisi di atas, maka setiap organisasi mempunyai kewajiban untuk menghargai karyawannya dengan memberikan kompensasi sesuai dengan kontribusi yang diberikan karyawan kepada organisasi. Kompensasi yang diberikan kepada karyawan dapat berupa finansial maupun non finansial yang diperlukan oleh karyawan untuk memenuhi kebutuhan hidupnya dan juga untuk mendukung pelaksanaan pekerjaannya. Terpenuhinya kebutuhan ini merupakan hal penting, baik bagi karyawan dan organisasi dalam mencapai tujuan yang telah ditetapkan.

Dari pendapat para ahli yang disampaikan di atas, maka untuk membahas mengenai kompensasi diambil satu pendapat dari Ambar Teguh Sulistiyani dan Rosidah (2003:206), mendefinisikan "Kompensasi adalah segala sesuatu yang diterima oleh pegawai sebagai balas jasa (kontra prestasi) atas kerja mereka". Pada dasarnya kompensasi merupakan kontribusi yang diterima oleh pegawai atas pekerjaan yang telah dikerjakannya.

Kinerja (performance) merupakan bagian dari produktivitas kerja, produktivitas berasal dari kata produktif artinya sesuatu yang mengandung potensi untuk digali, sehingga produktivitas dapat dikatakan sesuatu proses kegiatan yang terstruktur guna menggali potensi yang ada dalam sebuah komoditi atau objek. Filosofi produktivitas sebenarnya dapat mengandung arti keinginan dan usaha dari setiap manusia (individu maupun kelompok) untuk selalu meningkatkan mutu kehidupan dan penghidupannya. Seperti yang disebutkan dalam Al Qur'an Surat At Taubah (9: 105) "Dan katakanlah: bekerjalah kamu, maka Allah akan melihat pekerjaanmu begitu juga Rosulnya dan orang-orang mukmin, dan kamu akan dikembalikan kepada (Allah) yang mengetahui yang gaib dan yang nyata, lalu diberitakannya kepada kamu apa yang telah kamu kerjakan." Melihat dalam surat ini dapat diartikan menilai pekerjaan yang telah kita kerjakan.

Berdasarkan peraturan pemerintah nomor 46 tahun 2011 tentang penilaian prestasi kerja, "Penilaian prestasi kerja pegawai negeri sipil (PNS) adalah suatu proses penilaian secara sistematis yang dilakukan oleh pejabat penilai terhadap sasaran kerja pegawai dan perilaku kerja pegawai negeri sipil, 
Prestasi kerja adalah hasil kerja yang dicapai oleh setiap Pegawai negeri sipil pada satuan organisasi sesuai dengan sasaran kerja pegawai dan perilaku kerja”. Prestasi kerja merupakan hasil kerja (kinerja), yang dicapai oleh setiap pegawai pada satuan organisasi atau instansi, sesuai dengan sasaran kerja pegawai serta perilaku kerja yang dinilai oleh pejabat penilai seorang pegawai. Sasaran kerja merupakan rencana serta target capaian yang disusun oleh setiap pegawai, yang harus dapat dicapai dalam periode penilaian. Sedangkan target yang akan dicapai, merupakan jumlah seluruh beban kerja atau tugas-tugas yang diemban seorang pegawai untuk dapat dilaksanakan.

"Penilaian pekerjaan adalah suatu metode untuk membandingkan berbagai pekerjaan dengan menggunakan prosedur-prosedur formal dan sistematis untuk menentukan urutan pekerjaan-pekerjaan melalui penentuan kedudukan dan rasio antara satu pekerjaan dengan yang lainnya", Sinambela (2016:478). Hasil dari penilaian ini disebut sebagai kinerja, yang dapat dijadikan sebagai dasar untuk memberikan sistem kompensasi yang dirasakan adil oleh pegawai.

Menurut Helfert (1996) dalam Rivai (2014:447), "Kinerja adalah suatu tampilan keadaan secara utuh atas perusahaan selama periode waktu tertentu, merupakan hasil atau prestasi yang dipengaruhi oleh kegiatan operasional perusahaan dalam memanfaatkan sumber-sumber daya yang dimiliki”.

Kinerja pegawai tidak datang dengan sendirinya, kinerja pegawai harus dikelola oleh pimpinan dalam suatu organisasi. Sama halnya dalam penyelesaian masalah dalam suatu organisasi, pemimpin harus dapat memberikan pemecahannya yang terkait dengan kinerja

Istilah kinerja berasal dari kata job performance atau actual performance (prestasi kerja atau prestasi yang sesungguhnya yang dicapai oleh seseorang). Pengertian kinerja (prestasi kerja) menurut Mangkunegara (2013:67), "Kinerja adalah hasil kerja secara kualitas dan kuantitas yang dicapai oleh seseorang pegawai dalam melaksanakan tugasnya sesuai dengan tanggung jawab yang diberikan kepadanya".

Kinerja (performance) mengacu kepada pencapaian tugas-tugas yang membentuk sebuah pekerjaan karyawan. Kinerja merefleksikan seberapa baik karyawan memenuhi persyaratan sebuah pekerjaan Simamora (2003:339). Dari pengertian tersebut dapat disimpulkan bahwa kinerja karyawan adalah tingkatan sejauh mana hasil karyawan dalam pencapaian tugas yang diberikan oleh perusahaan. Untuk mengetahui kinerja karyawan, maka perlu diadakan penilaian terhadap kinerja tersebut, dari penilaian dapat diketahui apakah kinerja yang dihasilkan karyawan memenuhi standar atau tidak. Dengan penilaian kinerja maka organisasi dapat memperbaiki kinerja karyawan, lebih memotivasi karyawan agar mau mengembangkan diri serta sebagai dasar perencanaan dan pengambilan keputusan dalam organisasi.

Menurut Michael Armstrong (2006:1) dalam Edison dan kawan-kawan (2016:190) "Performance management can be defined as a systematic process for improving organizational performance by developing the performance of individual and teams". Artinya manajemen kinerja dapat didefinisikan sebagai suatu proses yang sistematis untuk meningkatkan kinerja organisasi dengan mengembangkan kinerja individu dan tim.

Dengan demikian, dapat dimaknai bahwa kinerja yang optimal dan stabil bukanlah sesuatu yang kebetulan. Tentunya sudah melalui tahapan dengan manajemen kinerja yang baik dan usaha maksimal untuk mencapainya. Tanpa melaui manajemen kinerja yang baik, memungkinkan hasil yang dibanggakan sesungguhnya semu, sehingga keberhasilan merupakan suatu kebetulan yang bukan didasarkan pada pondasi yang kuat.

Kinerja adalah hasil dari suatu proses yang mengacu dan diukur selama periode waktu tertentu berdasarkan ketentuan atau kesepakatan yang telah ditetapkan sebelumnya, Emron Edison dan kawan-kawan (2016:190).

Dari beberapa pendapat para ahli tentang kinerja, diambil satu pendapat yaitu menurut Emron Edison dan kawan-kawan (2016:190), "Kinerja adalah hasil dari suatu proses yang mengacu dan diukur selama periode waktu tertentu berdasarkan ketentuan atau kesepakatan yang telah ditetapkan sebelumnya."

"Jabatan fungsional perekayasa adalah jabatan fungsional yang mempunyai ruang lingkup, tugas, tanggung jawab, dan wewenang untuk melakukan kegiatan kerekayasaan dalam suatu kelompok kerja fungsional pada bidang penelitian terapan, 
pengembangan, perekayasaan, dan pengoperasian yang diduduki oleh Pegawai Negeri Sipil dengan hak dan kewajiban yang diberikan secara penuh oleh pejabat yang berwenang". Dalam Perka BPPT nomor 105 tahun 2013.

\section{METODE PENELITIAN}

Metode penelitian adalah cara yang digunakan oleh peneliti dalam mengumpulkan data penelitiannya. Variasi metode dimaksud adalah: angket, wawancara, pengamatan atau observasi, tes dan dokumentasi Arikunto (2013:203).

Penelitian ini menggunakan metode kuantitatif, yaitu "metode yang berlandaskan pada filsafat positivisme, digunakan untuk meneliti pada populasi atau sampel tertentu, pengumpulan data menggunakan instrument penelitian, analisis data bersifat kuantitatif/statistik dengan tujuan untuk menguji hipotesis yang telah ditetapkan" menurut Sugiyono (2016:11).

Penelitian bertujuan untuk menguji pengaruh kepemimpinan terhadap kinerja jabatan fungsional, dan mengetahui pengaruh kompensasi terhadap kinerja jabatan fungsional perekayasa pada Pusat Penelitian dan Pengembangan Jalan dan Jembatan Kementerian Pekerjaan Umum dan Perumahan Rakyat.

Berdasarkan jenis pengumpulannya data dapat didapat dari sumber primer, dan sumber sekunder. Menurut Sugiyono (2015:225), "Sumber primer adalah sumber data yang langsung memberikan data kepada pengumpul data, dan sumber sekunder merupakan sumber yang tidak langsung memberikan data kepada pengumpul data, misalnya lewat orang lain atau dokumen".

Maka dari pendapat tersebut dapat disimpulkan bahwa jenis data terdiri dari data primer dan data sekunder, data primer adalah data yang diperoleh secara langsung melalui pengamatan (observasi), wawancara (interview), kuesioner (angket). Sedangkan untuk data sekunder ialah data yang tidak diterima secara langsung, yaitu dengan cara membaca dari sumber berupa buku, majalah, makalah, dokumen, dan jurnal.
Menurut Sugiyono (2015:38) "Variabel penelitian pada dasarnya adalah segala sesuatu yang berbentuk apa saja yang ditetapkan oleh peneliti untuk dipelajari sehingga diperoleh informasi tentang hal tersebut, kemudian ditarik kesimpulannya". Berdasarkan dari beberapa pendapat di atas maka dapat disimpulkan bahwa variabel penelitian adalah suatu atribut atau sifat atau nilai dari orang, obyek atau kegiatan yang mempunyai variasi tertentu yang ditetapkan oleh peneliti untuk dipelajari dan kemudian ditarik kesimpulannya.

Dari macam-macam variabel di atas, maka yang digunakan dalam penelitian ini ialah variabel independen dan dependen. Variabel independen (bebas) ialah kepemimpinan (X1), kompensasi (X2) serta variabel dependen (terikat) ialah kinerja $(\mathrm{Y})$.

\section{HASIL DAN PEMBAHASAN}

\section{Pengaruh Kepemimpinan Terhadap Kinerja}

Unsur -unsur kepemimpinan yang dinilai oleh responden meliputi: Strategi dikomunikasikan pimpinan dan cara penyampaiannya sangat jelas serta dapat diterima dengan baik, saya percaya bahwa tujuan yang ditetapkan pimpinan akan membawa perubahan yang lebih baik, pimpinan selalu memberikan perhatian secara personal dan sangat memotivasi kerja, pimpinan selalu peduli terhadap setiap permasalahan yang terjadi, pimpinan tidak memperhatikan lingkungan kerja dan saya merasa kurang nyaman dalam bekerja, pimpinan merangsang anggota untuk membekali diri dengan pengetahuan dan keahlian dalam usaha meningkatkan kompetensi, pimpinan merangsang anggota untuk memiliki tekad dalam menyelesaikan tugas dengan tuntas, pimpinan selalu berorientasi pada penyelesaian tugas tanpa memperhatikan kualitas, pimpinan selalu mengajak anggota untuk bekerja dalam tim yang solid dan harmonis, pimpinan selalu dapat menyelesaikan setiap konflik antar anggota dengan baik, pimpinan selalu menghargai setiap perbedaan pendapat untuk tujuan ke arah yang lebih baik, dan pimpinan selalu mengajak seluruh anggotanya untuk menghormati perbedaan dan keyakinan. 
Tabel 1. Rekapitulasi Tanggapan Responden Berkaitan dengan Kepemimpinan

\begin{tabular}{|c|c|c|c|c|c|}
\hline No & Pernyataan & $\begin{array}{l}\text { Total } \\
\text { skor }\end{array}$ & $\begin{array}{c}\% \\
\text { Capaian }\end{array}$ & $\begin{array}{c}\text { Nilai } \\
\text { Harapan }\end{array}$ & Kriteria \\
\hline 1. & $\begin{array}{l}\text { Strategi dikomunikasikan pimpinan dan cara penyampaiannya sangat jelas } \\
\text { serta dapat diterima dengan baik }\end{array}$ & 117 & 80,7 & 145 & Baik \\
\hline 2 & $\begin{array}{l}\text { Saya percaya bahwa tujuan yang ditetapkan pimpinan akan membawa } \\
\text { perubahan yang lebih baik }\end{array}$ & 125 & 86,2 & 145 & $\begin{array}{l}\text { Sangat } \\
\text { baik }\end{array}$ \\
\hline 3 & $\begin{array}{l}\text { Pimpinan selalu memberikan perhatian secara personal dan sangat } \\
\text { memotivasi kerja }\end{array}$ & 114 & 78,6 & 145 & Baik \\
\hline 4 & Pimpinan selalu peduli terhadap setiap permasalahan yang terjadi & 114 & 78,6 & 145 & Baik \\
\hline 5 & $\begin{array}{l}\text { Pimpinan tidak memperhatikan lingkungan kerja dan saya merasa kurang } \\
\text { nyaman dalam bekerja }\end{array}$ & 110 & 75,9 & 145 & Baik \\
\hline 6 & $\begin{array}{l}\text { Pimpinan merangsang anggota untuk membekali diri dengan pengetahuan } \\
\text { dan keahlian dalam usaha meningkatkan kompetensi }\end{array}$ & 119 & 82,1 & 145 & Baik \\
\hline 7 & $\begin{array}{l}\text { Pimpinan merangsang anggota untuk memiliki tekad dalam menyelesaikan } \\
\text { tugas dengan tuntas }\end{array}$ & 120 & 82,8 & 145 & Baik \\
\hline 8 & $\begin{array}{l}\text { Pimpinan selalu berorientasi pada penyelesaian tugas tanpa memperhatikan } \\
\text { kualitas }\end{array}$ & 112 & 77,2 & 145 & Baik \\
\hline 9 & $\begin{array}{l}\text { Pimpinan selalu mengajak anggota untuk bekerja dalam tim yang solid dan } \\
\text { harmonis }\end{array}$ & 114 & 78,6 & 145 & Baik \\
\hline 10 & $\begin{array}{l}\text { Pimpinan selalu dapat menyelesaikan setiap konflik antar anggota dengan } \\
\text { baik }\end{array}$ & 109 & 75,2 & 145 & Baik \\
\hline 11 & $\begin{array}{l}\text { Pimpinan selalu menghargai setiap perbedaan pendapat untuk tujuan ke arah } \\
\text { yang lebih baik }\end{array}$ & 116 & 80,0 & 145 & Baik \\
\hline \multirow[t]{2}{*}{12} & $\begin{array}{l}\text { Pimpinan selalu mengajak seluruh anggotanya untuk menghormati perbedaan } \\
\text { dan keyakinan }\end{array}$ & 118 & 81,4 & 145 & Baik \\
\hline & & 116 & 79,75 & 145 & Baik \\
\hline
\end{tabular}

Berdasarkan tabel di atas, tanggapan responden berkaitan dengan kepemimpinan dinilai oleh responden baik, skor capaian sebesar 79,75\%. Dengan skor capaian penilaian tersebut secara umum, kepemimpinan memiliki kriteria baik dengan total skor rata-rata 116.

Hasil perhitungan pengaruh kompensasi terhadap kinerja dapat digambarkan berikut ini:

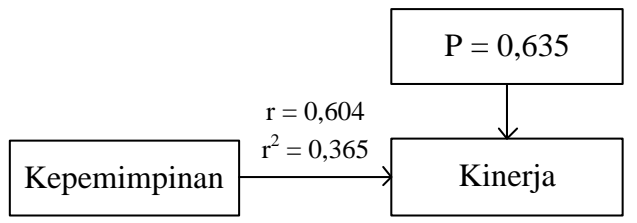

Berdasarkan gambar, variabel kepemimpinan berpengaruh terhadap kinerja dengan koefisien korelasi R sebesar 0,604, memiliki pengaruh secara positif dengan tingkat pengaruh kuat. Sedangkan nilai determinasi $\mathrm{R}^{2}$ sebesar 0,365 atau $36,5 \%$, dengan nilai signifikansi sebesar 0,001 $(0,001<$ $0,05)$.
Berdasarkan hal tersebut dapat dijelaskan bahwa kepemimpinan berpengaruh secara signifikan terhadap kinerja, adapun besarnya pengaruh yang diberikan oleh kepemimpinan yaitu sebesar 36,5\% dan sisanya $63,5 \%$ dipengaruhi oleh faktor lain yang tidak diteliti. Hal ini sesuai dengan hasil penelitian Erwin Dinata dkk. dalam jurnal yang berjudul Pengaruh kepemimpinan dan kompensasi terhadap kinerja pegawai Petugas Penyuluh Lapangan (PPL) Pada badan pelaksana penyuluhan dan Ketahanan pangan Kabupaten Siak, bahwa kinerja dipengaruhi oleh kepemimpinan dan kompensasi.

\section{Pengaruh Kompensasi Terhadap Kinerja}

Unsur-unsur kompensasi yang dinilai oleh responden meliputi: fasilitas yang didapatkan kurang memadai dalam melaksanakan aktivitas kerja, lingkungan kerja saat ini dirasakan kurang nyaman, sehingga kurang mendukung pelaksanaan pekerjaan yang saya laksanakan, dan saya mendapatkan tunjangan kesehatan (BPJS) sesuai dengan ketentuan yang diatur dalam perundang-undangan. 
Tabel 2. Rekapitulasi Tanggapan Responden Berkaitan dengan Kompensasi

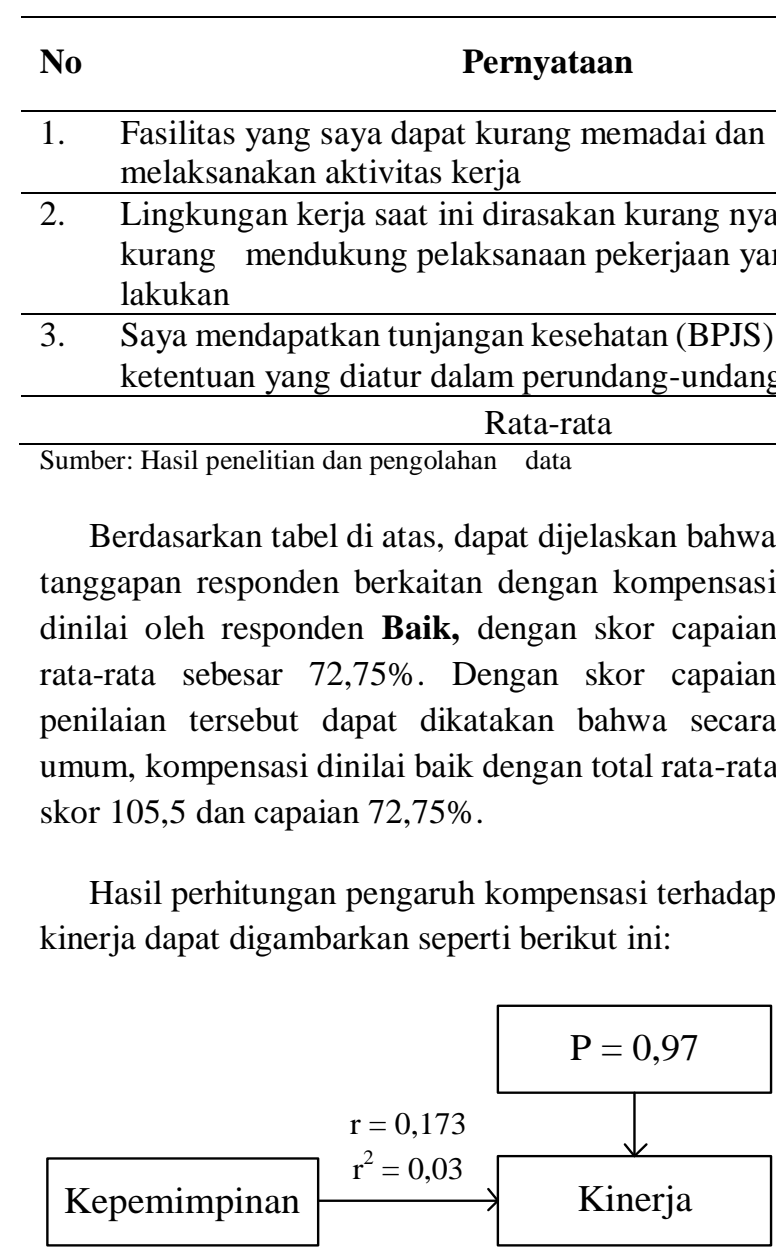

Berdasarkan gambar di atas, menunjukkan bahwa pengaruh yang diberikan kompensasi terhadap kinerja sebesar $R=0,173$, memiliki pengaruh secara positif dengan tingkat pengaruh sangat lemah. Sedangkan nilai determinasi $\mathrm{R}^{2}$ sebesar 0,03 atau $3 \%$, dengan nilai signifikansi sebesar 0,368 $(0,368>0,05)$ Berdasarkan hal tersebut dapat dijelaskan bahwa kepemimpinan berpengaruh tidak signifikan terhadap kinerja, adapun besarnya pengaruh yang diberikan oleh kompensasi yaitu sebesar 3\% dan sisanya 97\% dipengaruhi oleh faktor lain yang tidak diteliti.

\section{Kinerja}

Unsur-unsur kinerja yang dinilai oleh responden meliputi: dalam bekerja saya selalu berpedoman pada target yang harus dipenuhi atau diselesaikan, target yang saya buat/terima, sangat menantang namun realistis, saya selalu memenuhi kuantitas yang sudah ditargetkan, pelanggan internal puas atas kuantitas yang dihasilkan, hasil proyek sesuai dengan standar yang ditetapkan, Kualitas adalah hasil pekerjaan apa adanya, oleh karena itu nilai kualitas tidak harus dipenuhi, untuk memenuhi kualitas yang baik, saya selalu bekerja berdasarkan prosedur-prosedur yang ada, pelanggan internal/eksternal puas atas kualitas yang saya hasilkan, dalam menyelesaikan target, saya tidak selalu tepat waktu, bagi saya, penyelesaian kerja tepat waktu itu tidak penting dan tidak harus dicapai, proses yang saya lakukan berdasarkan pada cara-cara yang benar, dan proses yang saya lakukan

\section{KESIMPULAN DAN SARAN}

Berdasarkan hasil penelitian tentang Pengaruh Kepemimpinan dan Kompensasi Terhadap Kinerja Jabatan Fungsional Perekayasa di Lingkungan Pusatlitbang Jalan Dan Jembatan, maka dapat ditarik kesimpulan sebagai berikut:

1. Variabel kepemimpinan (X1) mempunyai pengaruh positif terhadap kinerja jabatan fungsional perekayasa (Y) sebesar 36,5\%, dengan koefisien korelasi $\mathrm{R}$ sebesar 0,604. Sehingga dapat disimpulkan variabel kepemimpinan memiliki pengaruh secara positif dengan tingkat pengaruh yang kuat.

2. Variabel kompensasi (X2) mempunyai pengaruh positif terhadap kinerja jabatan fungsional perekayasa (Y) sebesar 3\%, dengan koefisien korelasi $\mathrm{R}$ sebesar 0,173. Sehingga dapat disimpulkan variabel kompensasi memiliki pengaruh positif dengan tingkat pengaruh sangat lemah.

3. Secara simultan variabel kepemimpinan dan kompensasi berpengaruh terhadap kinerja dengan koefisien korelasi $\mathrm{R}=0,612$ atau determinan $\mathrm{R}^{2}$ sebesar 0,375 atau sebesar $37,5 \%$ dan sisanya sebesar $62,5 \%$ dipengaruhi oleh faktor lain yang 
tidak diteliti. Nilai signifikan yang diperoleh yaitu sebesar 0,002. Sehingga $0,002<0,05$ yang artinya bahwa Ho ditolak dan $\mathrm{H} 1$ diterima, hal ini menunjukan bahwa variabel kepemimpinan dan kompensasi berpengaruh signifikan terhadap kinerja.

Berdasarkan hasil penelitian tentang Pengaruh Kepemimpinan dan Kompensasi Terhadap Kinerja Jabatan Fungsional Perekayasa di Lingkungan Pusatlitbang Jalan Dan Jembatan, maka dapat disampaikan saran sebagai berikut:

1) Setiap pegawai (pejabat fungsional perekayasa) ingin diperlakukan secara adil oleh pimpinan, tidak saja dalam hubungannya dengan upah, tetapi juga dalam hal-hal lain, untuk dapat menciptakan persepsi yang sama antara atasan dengan bawahan maka perlu diadakan komunikasi yang terbuka. Misalnya dengan menyapa setiap pegawai, memberikan salam di pagi hari pada saat masuk kerja.

2) Para pegawai (pejabat fungsional perekayasa) menginginkan agar hasil karyanya dihargai, hal ini bertujuan agar pegawai merasa senang dalam bekerja dan akan selalu bekerja dengan segiat-giatnya. Hal ini dapat diatasi melalui komunikasi dua arah secara timbal balik.

3) Faktor utama dalam pekerjaan, meliputi upah/gaji, pengawasan, ketentraman kerja, kondisi kerja dan kesempatan untuk maju. Kesempatan untuk maju, yaitu ada tidaknya kesempatan untuk memperoleh pengalaman dan peningkatan kemampuan selama kerja.

4) Pimpinan perlu memperhatikan Kondisi kerja, termasuk kondisi tempat, ventilasi, kantin serta tempat parkir.

5) Manajemen sebaiknya menjaga dan meningkatkan kinerja pegawai terutama menyangkut kualitas kerja melalui program pelatihan secara berkala, kemudian pimpinan perlu mengefektifkan fungsi pengawasan serta pemberian reward and punishment yang objektif dan transparan kepada pegawai, sehingga pegawai menjadi lebih baik dalam mengoptimalkan waktu dalam menyelesaikan pekerjaan pada masa yang akan datang.

6) Bagi peneliti selanjutnya disarankan untuk memperhatikan variabel-variabel lain yang berpengaruh terhadap kinerja pegawai diluar kepemimpinan dan kompensasi, mengingat masih banyaknya keterbatasan dalam penelitian ini.

\section{DAFTAR PUSTAKA}

Al Qur'an. 2009. AL Qur'an Ku Dengan Tajwid Blok Warna Disertai Terjemahan. Jakarta: Lautan Lestari.

A.A.Anwar Prabu Mangkunegara. 2013. Manajemen Sumber Daya Manusia Perusahaan, Cetakan ke-11.Bandung: Remaja Rosdakarya.

Dalman. 2015. Menulis Karya Ilmiah. Jakarta: PT. Raja Grafindo Persada.

Dedy Mulyadi. 2015. Prilaku Organisasi dan Kepemimpinan Pelayanan. Bandung: Alfabeta.

Emeron Edison dkk. 2016. Manajamen Sumber Daya Manusia. Bandung: Alfabeta.

Erwin Dinata dkk. 2014. Pengaruh Kepemimpinan Dan Kompensasi Terhadap Kinerja Pegawai Petugas Penyuluh Lapangan (PPL) Pada Badan Pelaksana Penyuluh Dan Ketahanan Pangan Kabupaten Siak. Jurnal Tepak Manajemen Bisnis. Universitas Riau. Vol. VI No.2.

Fauzan Muttaqien. 2014. Pengaruh Kepemimpinan Dan Kompensasi Terhadap Kepuasan kerja Karyawan Outsourcing Pada PT. BRI (Persero) TBK Cabang Lumajang. Jurnal WIGA STIE Widya Gama Lumajang. ISSN: 2088-0944.

Henry Simamora. 2004. Manajemen Sumber Daya Manusia Edisi III. Yogyakarta: STIE YKPN.

I Made Adi Suryadharma dkk. 2016. Pengaruh Kepemimpinan Dan Kompensasi Terhadap Kepuasan Kerja Dan Kinerja Karyawan (Studi Pada PT. BPR Sri Artha Lestari Denpasar). E-Jurnal Ekonomi dan Bisnis Universitas Udayana. ISSN: 2337-3067.

I Wayan Niko Susanta dkk. 2013. Pengaruh Kompensasi dan Kepemimpinan terhadap Kinerja Karyawan Pada Jasa Konstruksi di Denpasar. Jurnal Ilmiah Elektronik Infrastruktur Teknik Sipil Universitas Udayana, Volume 2, No. 2.

Lijan Poltak Sinambela. 2016. Manajemen Sumber Daya Manusia. Jakarta: Bumi Aksara.

Malayu Hasibuan. 2007. Organisasi \& Motivasi. Cetakan ke-5. Jakarta: Bumi Aksara. 
Maman Suratman. 2016. Himpunan Materi Metodologi Penelitian. Bandung: Ikopin.

Miftah Thoha.2005. Perilaku Organisasi. Cetakan ed. 1-16. Jakarta: PT. Raja Grafindo Persada.

Pedoman Penulisan Tesis Program Pasca Sarjana. Bandung: Ikopin Tahun 2016.

Ria Gustaman. 2016. Modul Kuliah Statistika. Bandung: Ikopin.

Robbins, Stephen P. Judge, T.A. 2015. Perilaku Organisasi. Jakarta: Salemba Empat

Rosidah dan Ambar Teguh Sulistiyani. 2003. Manajemen Sumber Daya Manusia. Yogyakarta: Graha Ilmu.

Sedarmayanti. 2011. Membangun dan Mengembangkan Kepemimpinan Serta Meningkatkan Kinerja Untuk Meraih Keberhasilan. Bandung. Refika Aditama.

2016. Manajemen Sumber Daya

Manusia- Reformasi Birokrasi dan Manajemen Pegawai Negeri Sipil.Bandung: Refika Aditama.

Sugiyono. 2015. Metode Penelitian Kuantitatif kualitatif Dan R\&D. Bandung: Alfabeta.

2016. Metode Penelitian Kombinasi

(Mix Methods). Bandung: Alfabeta.

Suharsimi Arikunto. 2013. Prosedur Penelitian Suatu Pendekatan Praktik. Jakarta: Rineka Cipta.

Suparyadi. 2015. Manajemen Sumber Daya Manusia Menciptakan Keuanggulan Bersaing Berbasis Kompetensi SDM. Yogyakarta: Andi.

Suryani Hendryadi. 2015. Metode Riset Kuantitatif Teori dan Apikasi Jakarta: Prenadamedia Group.

Suwatno dan D. Juni Priansa. 2016. "Manajemen SDM Dalam Organisasi Publik dan Bisnis". Bandung: Alfabeta.

Syamsir Torang. 2014. Organisasi dan Manajemen (Prilaku, Struktur, Budaya \& Perubahan Organisasi). Bandung: Alfabeta.
Terry, R. George. Rue W. Leslie.2015. Dasar Dasar Manajemen. Cetakan ke 16. Jakarta: Bumi Kasara.

Trida Gunadi. 2016. Modul Kuliah Metodologi Penelitian. Bandung: Ikopin.

T. Hani Handoko. 2001. Manajemen Personalia dan Manajemen Sumber Daya Manusia, Yogyakarta: BPFE UGM.

Ulber Silalahi. 2002. Pemahaman Praktis Asas-Asas Manajemen. Cetakan II. Bandung: Mandar Maju.

Veitzhal Rivai. dkk. 2014. Manajemen Sumber daya manusia Untuk Perusahaan Dari Teori ke Praktek. Jakarta: PT. Raja Grafindo Persada.

Wibowo. 2016. Prilaku Dalam rganisasi. Jakarta: PT. Raja Grafindo Persada.

Undang-undang nomor 24 tahun 2011 tentang Badan Penyelenggara Jaminan Sosial (BPJS) Peraturan Pemerintah Republik Indonesia Nomor 46 Tahun 2011. Tentang Penilaian Prestasi Kerja Pegawai Negeri Sipil.

Peraturan Presiden Republik Indonesia Nomor 86 Tahun 2013. Tentang Tunjangan Kinerja Pegawai Di Lingkungan Kementerian Pekerjaan Umum

Peraturan Presiden Nomor 152 Tahun 2015 tentang Tujangan Kinerja Pegawai di Lingkungan Kementerian Pekerjaan Umum dan Perumahan Rakyat

Peraturan Menteri Pekerjaan Umum Nomor. 20/PRT/M/2016 tentang Organisasi dan Tata Kerja Unit Pelaksana Teknis di Kementerian Pekerjaan Umum dan Perumahan Rakyat

Peraturan Kepala Badan Pengkajian dan Penerapan Teknologi Nomor 105 Tahun 2013 Tentang Petunjuk teknis Jabatan Fungsional Perekayasa dan Angka Kreditnya.

Keputusan Menteri Pendayagunaan Aparatur Negara Nomor PER/2I9/M. PAN/7/2O08 tentang Jabatan Fungsional Perekayasa dan Angka Kreditnya 
